\title{
Retrieval Impairment in Generalized Tonic-Clonic Epilepsy and Complex Partial Epilepsy
}

\author{
Rimawati Tedjasukmana, Lily D. Sidiarto, Sidiarto Kusumoputro
}

\begin{abstract}
Abstrak
Banyak penderita epilepsi mengeluhkan gangguan daya ingat, terutama epilepsi parsial kompleks. Selain itu daya ingat pada epilepsi dilaporkan dipengaruhi oleh faktor-faktor seperti jenis serangan, frekuensi serangan, umur pada serangan awal, obat-obatan, dll. Tetapi data-data yang ada dari hasil penelitian masih membingungkan.Untuk mengevaluasi ritrival pada penderita epilepsi digunakan Test Pengingatan Selektif pada 44 penderita epilepsi (30 penderita epilepsi umum tonik-klonik dan 14 penderita epilepsi parsial kompleks) yang berobat di Poliklinik Saraf RSCM selama periode satu tahun. Setelah dilakukan tes dinilai skor ritrival dan penimbunan. Kemudian gangguan ritrival dianalisis terhadap beberapa variabel: jenis serangan, frekuensi serangan, umur pada serangan awal dan dosis obat (fenobarbital). Juga dilakukan analisis proses daya ingat yang terganggu pada penderita yang ritrivalnya buruk. Pada sebagian besar (75\%) kasus epilepsi ditemukan skor ritrivalnya buruk. Pada kelompok epilepsi umum-tonik klonik rata-rata skornya 7,77, sedangkan pada epilepsi parsial kompleks 8,36. Skor ritrival tidak dipengaruhi oleh jenis serangan, frekuensi serangan dan dosis obat. Walaupun secara statistik tidak bermakna, terdapat kecenderungan skor yang buruk lebih banyak terdapat pada kelompok dengan serangan awal pada usia kurang dari 10 tahun. Pada analisis proses daya ingat yang terganggu ditemukan bahwa walaupun rata-rata penimbunan awal dan ritrival pada kedua jenis epilepsi tak jauh berbeda, tetapi rasio penimbunan'ritrival pada epilepsi parsial kompleks lebih baik dibanding dengan epilepsi umum tonik-klonik. Jadi pada kelompok epilepsi parsial kompleks penimbunan terjadi lebih dini. Sebagian besarkasus skor ritrivalnya buruk dan hal ini tak dipengaruhi oleh jenis serangan, frekuensi serangan, serangan awal maupun dosis obat anti-epilepsi. Jadi kemungkinan gangguan retrival pada epilepsi merupakan akibat multifaktorial. Pada epilepsi umum tonik-klonik selain gangguan ritrival terjadi gangguan penimbunan, hal ini kemungkinan terjadi karena gangguan atensi.
\end{abstract}

\begin{abstract}
Many epileptic patients complain of poor memory, especially those with complex partial seizures. Memory in epilepsy is reportedly influenced by several factors like seizure type, seizure frequency, age at onset of epilepsy, anti-epileptic medication, etc. However, the available data are somewhat confusing and do not provide any clear answers. In order to evaluate retrieval in epileptic patients the Selective Reminding Test was used in 44 epilepsy patients (30 with generalized tonic-clonic epilepsy and 14 with partial complex epilepsy) who were treated in the outpatient clinic of the Department of Neurology of the Dr Cipto Mangunkusumo Hospital during one year period (1993-1994). All subjects had passed elementary school, were without severe brain damage, had their last seizure more than 24 hours ago and only take one anti-epileptic drug (phenobarbital). Retrieval impairment was analyzed with respect to the following variables: seizure type, seizure frequency, age at onset and drug dose. In subjects with impaired retrieval the memory process were analyzed. Impaired retrieval was found in most subjects (75\%). The mean retrieval scores were 7.77 for subjects with generalized tonic-clonic epilepsy and 8.36 for subjects with partial complex epilepsy. There is no correlation between seizure type and retrieval (t test). Most subjects had low frequency seizures, but mean retrieval scores were impaired both in the high frequency $(71 \%)$ and the low frequency (68\%) group (not significant with chi-square test). Although it was statistically not significant there was a tendency that the greatest retrieval impairment was in the group with early age at onset (less than 10 years). Although most subjects had low doses of phenobarbital, most of them had impaired retrieval. There is no correlation between drug dose and retrieval (chi-square). In analyzing the impaired memory processes although there was little difference in the initial storage and retrieval in both types of epilepsy, the storage/retrieval (S/R) ratio were better in complex partial epilepsy $(0,5$ or less) than in generalized tonic-clonic epilepsy (more than 0,5). In complex partial epilepsy initial storage occured earlier. Most epilepsy patients had impaired retrieval; and it was not influenced by seizure type, seizure frequency, age at onset and anti-epileptic drug dose. Impaired retrieval in epilepsy is probably a multifactorial disability. Also in generalized tonic-clonic epilepsy there was impaired initial storage besides retrieval, this was probably caused by disturbance of attention.
\end{abstract}

Keywords: epilepsy, seizure type, seizure frequency, age at onset, drug dose, selective reminding test, retrieval, storage.

Department of Neurology, Faculty of Medicine, University of Indonesia/Dr. Cipto Mangunkusumo Hospital, Jakarta, Indonesia
Epilepsy is one of the most frequent neurological disease, only stroke has a higher incidence. ${ }^{1}$ In several studies the incidence varies between 24-53 per 
100.000 and the prevalence is $4-8$ per 100.000 . The numbers were relatively constant in several countries. ${ }^{2}$ In Indonesia epidemiological study on epilepsy is not yet performed, but it was surmised that the incidence and prevalence is the same.

Traditional or conventional treatment in patients with epilepsy is directed to drug therapy adjustments based on the type, severity and frequency of seizures, and the side effects of anti-epileptic drugs. However, epileptic seizures and anti-epileptic drugs have a great impact on the life of a patient with epilepsy, i.e. psychosocial problems. Several factors influence the quality of life of the patient with epilepsy, i.e. seizure reccurency, psyhosocial adaptation, behavior disturbances, also deficit of cognitive function and behavior disturbances caused by anti-epileptic drugs.

Many epileptics, even those with mild symptoms, complain of poor memory. ${ }^{3}$ In clinical practice generally the patients were only treated with anti-epileptic drugs, the memory deficits went frequently unnoticed. However, this problem needs special attention as the patient requires a holistic treatment approach, including his social function.

Memory deficits in epileptic patients merit special attention since they seek help for these more frequently than for any other mental impairments. Interest in this area is not new; Tissot (1770), Gowers (1881), and Reynolds (1861) had discovered that memory impairment was frequently found in epileptics. ${ }^{4}$

In clinical practice memory disturbance is more frequently found in complex partial epilepsy. However, in many studies there is still disagreement whether there is a difference in the memory functions of complex partial and generalized tonic-clonic epilepsy. ${ }^{3,5,6,7}$ Most complex partial seizures derived from temporal and frontal lobe origin, ${ }^{1}$ furthermore $70-80 \%$ of temporal lobe epilepsy begin in the hippocampus. ${ }^{8}$ These facts are a little perplexing as we understand the important role of the temporal lobe and especially the hippocampus in memory functions.

Another problem is what other factors can influence memory. Besides seizure type, other fac- tors like seizure frequency, seizure onset, drugs, etc, had been reported to influence memory; however, other studies could not prove it. In developing countries like Indonesia drugs are more often chosen for their availability and their low prize, so many epileptics here use phenobarbital. Reports of deleterious effects of phenobarbital on cognitive function present an important question of how far it has reduced the human resources here.
In conclusion, the available data is somewhat confusing and do not give any clear answers to those questions. Probably this was caused by differences in the type of test used (many tests were not especially made for memory testing), the sampling method and usage of anti-epileptic drugs. In this study we propose to use a simple and widely used test that can show the differences in the memory process,i.e. the selective reminding test. Also the patients included in this study only used one kind of anti-epileptic drug (phenobarbital).

\section{MATERIALS AND METHODS}

\section{Subject}

Subjects were patients attending the outpatient clinic of the Department of Neurology of Dr. Ciptomangunkusumo Hospital and the Pemuda Neurologic Clinic, Jakarta, during one year period (1993-1994). All patients were confirmed to have epilepsy by history of seizures, neurological examination and/or EEG, and could be classified according to the International Classification of Seizures. Patients were selected for inclusion based on the criteria: minimum education primary school, no neurological signs on examination, use only one anti-epileptic drug (phenobarbital), and the last seizure was more than 24 hours ago.

The generalized tonic-clonic epilepsy group with generalized tonic-clonic seizures without aura and normal EEG or generalized epileptiform/slow wave bursts. The complex partial epilepsy group with partial seizures and loss of consciousness, not followed by generalized seizures at least during the previous year, and normal EEG or focal epileptiform/slow wave bursts. Patients with history of head trauma, CNS infection or neoplasm; with secondarily generalized seizures or generalized tonic-clonic seizures with focal bursts on EEG were excluded from the study. During one year period we found 44 cases which fulfilled the criteria, 30 cases generalized tonic-clonic epilepsy and 14 cases of complex partial epilepsy.

\section{Procedure}

Examinations were conducted in a quite and adequately lighted room. Name, gender, education, seizure type, EEG patterns, seizure frequency, age at onset, anti-epileptic drugs and dosage were recorded. Education was level of education passed in years. EEG was normal, with generalized or focal bursts of epileptiform/slow waves. 
The selective reminding test was administered to all subjects. The patient was asked to learn a list of 10 words by verbal recall in any order. The entire list was read aloud once to the patient at a 2 -second rate before his first recall attempt. The patient then tried to recall all of the words in the list in any order. The patient was selectively reminded only those items he did not recall on the immediate preceding trial before he again attempted to recall all items in the list. The procedure was continued until all 10 items could be recalled on 2 consecutive trials.

Retrieval score is the number of trials minus one. Buschke had discovered that recall failures represent retrieval failures rather than loss from storage. ${ }^{9}$ In conclusion recalled items are items retrieved from long term storage. Yunus found that the mean retrieval score was 4 or less in normal individuals, and it was not influenced by age or educational level. ${ }^{10}$ The subjects with poor retrieval scores were analyzed their storage/ retrieval ratio. Storage score is the number of trials when all items had entered storage. An item is considered in storage when the subject can recall the item without representation. Data were analyzed with $t$ test for 2 independent samples and the chi-square test.

\section{RESULTS}

During one year period we found 44 cases of epilepsy which fulfilled the study criteria, 30 cases with generalized tonic-clonic epilepsy and 14 with complex partial epilepsy. Descriptive information on the two groups included in this study is presented in Table 1. Between the two groups there were no significant differences in gender (chi-square test), age, education, and drug dose ( $\mathrm{t}$ test).

Table 1. Characteristics of the two groups of epilepsy

\begin{tabular}{|c|c|c|c|c|}
\hline & Characteristic & $\begin{array}{l}\text { Generalized } \\
\text { Tonic-clonic }\end{array}$ & $\begin{array}{c}\text { Complex } \\
\text { Partial }\end{array}$ & Statistic \\
\hline No. & & 30 & 14 & \\
\hline Age: & $\begin{array}{l}\text { - Mean } \\
\text { - SD }\end{array}$ & $\begin{array}{l}27.2 \\
7.38\end{array}$ & $\begin{array}{l}27.64 \\
10.99\end{array}$ & $N S^{a}$ \\
\hline Gender : & $\begin{array}{l}\text { - Male } \\
\text { - Female }\end{array}$ & $\begin{array}{l}18 \\
12\end{array}$ & $\begin{array}{l}6 \\
8\end{array}$ & $N S^{b}$ \\
\hline Education: & $\begin{array}{l}\text { - Mean } \\
\text { - SD }\end{array}$ & $\begin{array}{l}10.33 \\
2.5\end{array}$ & $\begin{array}{c}8.79 \\
3.2\end{array}$ & $N S^{a}$ \\
\hline Drug dose: & $\begin{array}{l}\text { e: - Mean } \\
\quad \text { - SD }\end{array}$ & $\begin{array}{l}114.5 \\
59\end{array}$ & $\begin{array}{c}114.64 \\
73.97\end{array}$ & $N S^{a}$ \\
\hline
\end{tabular}

\footnotetext{
${ }^{a} t$ test for 2 independent samples

${ }^{b}$ chi-square test with Yates correction
}

Both groups had the same distribution of seizure frequency with low seizure frequency in most cases. In the generalized tonic-clonic (GTC) group $56.67 \%$ (17 cases) and in the complex partial (CP) group $42.85 \%$ (6 cases) had less than 1 seizure per year. Only a few cases had high seizure frequency, 1 case (3.33\%) with GTC and 2 cases (14.29\%) with CP seizures. There was no difference in age at onset of seizures in both groups. Most cases had seizure onset in the age range of $10-17$ years, $43.33 \%$ (13 cases) in the GTC group and $57.14 \%$ ( 8 cases) in the CP group. In conclusion both groups had the same characteristics.

Table 2 lists the retrieval scores of both groups. The mean score of GTC group was 7.77 and CP group 8.36. Analysis with $t$ test for 2 independent samples with $\mathrm{df}$ 42 revealed no significant difference between the 2 groups $(\mathrm{p}>0,2)$.

From the 44 cases studied, 25\% (11 cases) had good retrieval with retrieval scores 4 or less and $75 \%$ (33 cases) had poor retrieval with scores more than 4 . More than half of the cases ( 23 cases) had less than 1 seizure per year (Table 3 ). However, nearly all cases had poor retrieval, and most cases with poor retrieval (36.78\%) had less than 1 seizure per year. So we can conclude that retrieval scores is not influenced by seizure frequency (chi-square test, $\mathrm{p}>0,2$ ).

The situation appears clearer when we simplify the seizure frequency to low (less than once per month) and high (once per month or more) frequency. In the high seizure frequency group 5 of 7 cases $(71 \%)$ had poor retrieval scores, meanwhile 17 of 25 patients (68\%) with low seizure frequency had poor retrieval scores (Figure 1). In conclusion both low and high seizure frequency groups had poor retrieval.

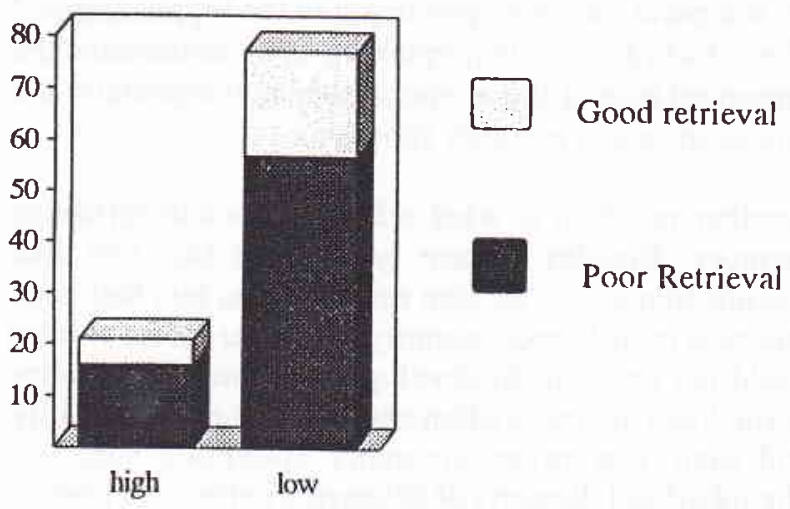

Figure 1. Seizure frequency and retrieval (in percent) 
Table 2. Seizure type and retrieval.

\begin{tabular}{|c|c|c|c|}
\hline \multicolumn{2}{|c|}{ Generalized Tonic-Clonic } & \multicolumn{2}{|c|}{ Complex Partial } \\
\hline No & Score & No & Score \\
\hline 1 & 15 & 1 & 15 \\
\hline 2 & 9 & 2 & 14 \\
\hline 3 & 8 & 3 & 10 \\
\hline 4 & 10 & 4 & 15 \\
\hline 5 & 3 & 5 & 4 \\
\hline 6 & 9 & 6 & 4 \\
\hline 7 & 15 & 7 & 4 \\
\hline 8 & 5 & 8 & 15 \\
\hline 9 & 14 & 9 & 5 \\
\hline 10 & 6 & 10 & 8 \\
\hline 11 & 10 & 11 & 6 \\
\hline 12 & 7 & 12 & 8 \\
\hline 13 & 3 & 13 & 6 \\
\hline 14 & 4 & 14 & 3 \\
\hline 15 & 7 & & \\
\hline 16 & 6 & & \\
\hline 17 & 6 & & \\
\hline 18 & 5 & & \\
\hline 19 & 3 & & \\
\hline 20 & 7 & & \\
\hline 21 & 4 & & \\
\hline 22 & 6 & & \\
\hline 23 & 11 & & \\
\hline 24 & 3 & & \\
\hline 25 & 15 & & \\
\hline 26 & 8 & & \\
\hline 27 & 8 & & \\
\hline 28 & 7 & & \\
\hline 29 & 15 & & \\
\hline 30 & 4 & & \\
\hline
\end{tabular}

Table 3. Seizure frequency and retrieval in both epilepsy groups

\begin{tabular}{lccc}
\hline Seizure & \multicolumn{2}{c}{ Retrieval } & Total \\
& Good & Poor & \\
\hline Once or more per week & 1 & 2 & 3 \\
& $(2.27 \%)$ & $(4.54 \%)$ & $(6.81 \%)$ \\
1 1-3 times a month & 1 & 5 & 6 \\
Less than once a month & $(2.27 \%)$ & $(11.37 \%)$ & $(13.64 \%)$ \\
Less than once a year & 3 & 9 & 12 \\
& $(6.82 \%)$ & $(20.45 \%)$ & $(27.27 \%)$ \\
Total & 6 & 17 & 23 \\
& $(13.64 \%)$ & $(36.78 \%)$ & $(52.28 \%)$ \\
& 11 & 33 & 44 \\
\hline
\end{tabular}

Age at onset in most cases $(47.73 \%)$ was in the range of $10-17$ years. In the group with age at onset under 10 years only 1 of 7 patients had good retrieval, in the 10-17 years group 7 of 14 patients and in the group with age at onset of more than 17 years 3 of 12 patients had good retrieval. Although it was statistically not significant (chi-square test), from this data we can conclude that there was a preponderance of poor retrieval scores in patients with early onset of seizures (Table 4 and Figure 2).

Table 4. Age at seizure onset and retrival in both types of epilepsy

\begin{tabular}{lccc}
\hline Age at onset & \multicolumn{2}{c}{ Retrieval } & Total \\
& Good & Poor & \\
\hline Under 10 years & 1 & 7 & 8 \\
& $(2.27 \%)$ & $(15.91 \%)$ & $(18.18 \%)$ \\
10-17 years & 7 & 14 & 21 \\
& $(15.91 \%)$ & $(31.82 \%)$ & $(47.73 \%)$ \\
More than 17 years & 3 & 12 & 15 \\
& $(6.82 \%)$ & $(27.27 \%)$ & $(34.09 \%)$ \\
Total & 11 & 33 & 15 \\
& $(25.00 \%)$ & $(75.00 \%)$ & $(100.00 \%)$ \\
\hline
\end{tabular}

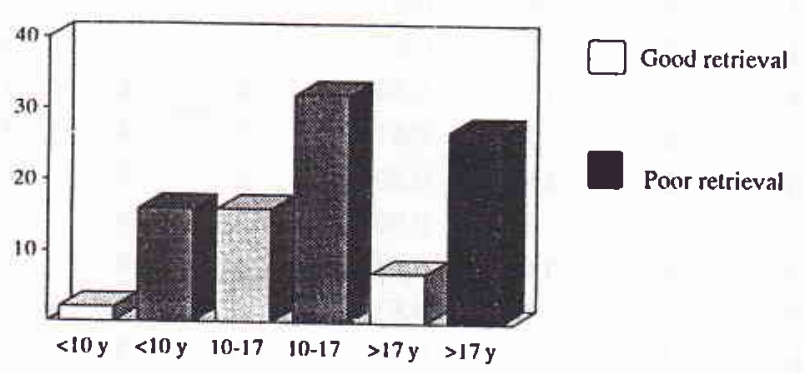

Figure 2. Age at onset and retrieval (in percentage)

Most patients $(40.91 \%)$ were receiving phenobarbital $51-100 \mathrm{mg}$ per day, only a few patients $(6.82 \%)$ received more than $200 \mathrm{mg}$ per day. However, most patients had poor retrieval, even those who received low doses of the drug (Table 5). Analysis with chisquare test revealed no relationship between drug dose and retrieval. 
Table 5. Drug dose and retrieval in both epilepsy types

\begin{tabular}{rccc}
\hline Drug dose & \multicolumn{2}{c}{ Retrieval } & Total \\
& Good & Poor & \\
\hline $0-50 \mathrm{mg}$ & 3 & 6 & 9 \\
& $(6.82 \%)$ & $(13.63 \%)$ & $(20.45 \%)$ \\
$51-100 \mathrm{mg}$ & 5 & 13 & 18 \\
& $(11.37 \%)$ & $(29.54 \%)$ & $(40.91 \%)$ \\
$101-150 \mathrm{mg}$ & 1 & 7 & 8 \\
& $(2.27 \%)$ & $(15.91 \%)$ & $(18.18 \%)$ \\
$151-200 \mathrm{mg}$ & 1 & 5 & 6 \\
& $(2.27 \%)$ & $(11.37 \%)$ & $(13.64 \%)$ \\
$201-250 \mathrm{mg}$ & 1 & 2 & 3 \\
& $(2.27 \%)$ & $(4.45 \%)$ & $(6.82 \%)$ \\
\hline
\end{tabular}

Analysis of the impaired memory proccess in the 2 types of epilepsy revealed no difference of mean values of initial storage, i.e. 5.4 for GTC and 5.3 for $\mathrm{CP}$ (Table 6). However, there was significant difference in the storage/retrieval (S/R) ratio, with $\mathrm{CP}$ seizures 0.5 or less and GTC more than 0.5 (Figure 3). So we conclude that initial storage occured ealier in the $\mathrm{CP}$ group.

\section{DISCUSSION}

During one year we found 44 cases which fulfilled the study criteria. This was a relatively small sample compared with other studies, but the advantage of this study was a more homogenous sample. In this study subjects were ambulatory epileptic patients using only one drug (phenobarbital) and without major CNS disturbances.

EEG with simultaneous video monitoring is not yet available in our country, so it is possible that patients with GTC seizures actually had partial secondarily generalized seizures. It is also possible that patients had subclinical seizures while undergoing the test that could influence the test results.

The 30 patients with GTC and 14 patients with CP had the same characteristics (age, gender, education, drug dosage). Most cases of both groups had less than 1 seizure a year, and age at onset from 10-17 years. We conclude that both groups were relatively similar and homogenous.

Table 6. Storage/Retrieval (S/R) ratio of both epilepsy types with poor retrieval.

\begin{tabular}{|c|c|c|c|c|c|c|c|}
\hline \multicolumn{4}{|c|}{ GTC } & \multirow[b]{2}{*}{ No } & \multicolumn{3}{|c|}{$\mathrm{CP}$} \\
\hline No & Storage & Retrieval & S/R ratio & & Storage & Retrieval & S/R ratic \\
\hline 1 & 7 & 15 & 0,47 & 1 & 15 & 15 & 1,00 \\
\hline 2 & 6 & 9 & 0,67 & 2 & 3 & 14 & 0,21 \\
\hline 3 & 7 & 8 & 0,87 & 3 & 3 & 10 & 0,30 \\
\hline 4 & 5 & 10 & 0,50 & 4 & 6 & 15 & 0,40 \\
\hline 5 & 6 & 9 & 0,67 & 5 & 4 & 15 & 0,27 \\
\hline 6 & 12 & 15 & 0,80 & 6 & 5 & 5 & 1,00 \\
\hline 7 & 3 & 5 & 0,60 & 7 & 4 & 8 & 0,50 \\
\hline 8 & 8 & 14 & 0,57 & 8 & 6 & 6 & 1,00 \\
\hline 9 & 5 & 6 & 0,83 & 9 & 4 & 8 & 0,50 \\
\hline 10 & 5 & 10 & 0,50 & 10 & 3 & 6 & 0,50 \\
\hline 11 & 4 & 7 & 0,57 & & & & \\
\hline 12 & 3 & 7 & 0,42 & & & & \\
\hline 13 & 4 & 6 & 0,67 & & & & \\
\hline 14 & 6 & 6 & 1,00 & & & & \\
\hline 15 & 4 & 5 & 0,80 & & & & \\
\hline 16 & 5 & 7 & 0,71 & & & & \\
\hline 17 & 4 & 6 & 0,67 & & & & \\
\hline 18 & 5 & 11 & 0,45 & & & & \\
\hline 19 & 5 & 15 & 0,33 & & & & \\
\hline 20 & 6 & 8 & 0,75 & & & & \\
\hline 21 & 6 & 8 & 0,75 & & & & \\
\hline 22 & 6 & 7 & 0,85 & & & & \\
\hline 23 & 4 & 15 & 0,27 & & & & \\
\hline
\end{tabular}

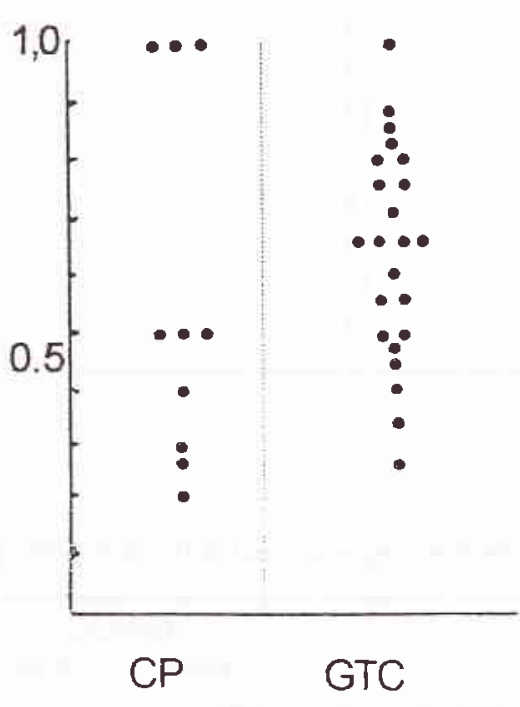

Figure 3. Storage/Retrieval ratio of both types of epilepsy with poor retrieval. 
Results of this study showed that patients with $\mathrm{CP}$ and GTC seizures had the same level of memory disturbance. Studies by Loiseau ${ }^{3}$ and Mayeux ${ }^{11}$ indicated the same results. Other investigators like Bornstein, ${ }^{5}$ Glowinski, ${ }^{12}$ Mungas, ${ }^{13}$ Smith, ${ }^{8}$ etc revealed that patients with $\mathrm{CP}$ seizures were at greater risk for memory difficulties compared to patients with GTC seizures. Meanwhile Matthews and Klove demonstrated on the contrary. ${ }^{14}$

Inconsistent findings seem to be influenced by differences in the patient population. Thompson presumed that memory impairment in patients with GTC was greater than patients with $\mathrm{CP}$ when the patients studied had less severe seizure disorders. ${ }^{15}$ However, in our opinion ambulatory epilepsy patients can give a clearer picture of memory impairment in epilepsy. Hospitalized patients usually have severe and frequent seizures, consequently there is permanent brain damage that can aggravate the memory difficulties. ${ }^{7,15}$ Also in patients with intractable seizures it is difficult to decide when to do the test, due to the frequent seizures.

Another explanation is that every disturbance in the CNS, like epileptic seizures or anoxia, causes the release of high concentrations of the neurotransmitter glutamate. The NMDA (N-Methyl-D-Aspartate) receptor, one of the glutamate receptors, resides mostly in the CA1 area of the hippocampus and is also present in the dentate gyrus and neocortex. Glutamate can destroy neurons in minutes, resulting in the destruction of the CA1 area. The CA1 area of the hippocampus plays a great role in long term potentiation, which is the basis of learning or long term memory. ${ }^{16}$ This fact was recognized since 1967 by Glaser who discovered that the limbic structure was very susceptible to pathologic processes including ischaemia, encephalitis and metabolic disturbances. ${ }^{17}$ In conclusion every seizure can cause destruction of $\mathrm{CA} 1$ cells resulting in memory impairments. Furthermore, in GTC seizures there are episodes of hypoxia that can aggravate the condition.

In clinical practice poor memory was more often complained by patients with complex partial seizures. This could be caused either by the seizure itself or by depression.Patients with temporal lobe epilepsy often have psychiatric disturbances like depression. Depression in these patient can be caused by social stigma, and also due to lesions in the limbic system which controls emotion. ${ }^{17}$
Both groups had poor retrieval scores (more than 4), i.e. 7.77 in the GTC group and 8.36 in the CP group. This fact conforms with the studies by Matthews and Klove, ${ }^{14}$ Loiseau et al ${ }^{3}$ and Smith et al, ${ }^{8}$ which found that memory impairment was greater in epileptic patients than normal control.

Memory impairment could also be caused by antiepileptic drugs, i.e. phenobarbital. Phenobarbital was known to have deleterious effects on the memory of patients with epilepsy. ${ }^{18,19}$ It was proved that memory impairment was greater in patients using phenobarbital compared to other drugs, although they had low blood levels of phenobarbital. ${ }^{19}$

In this study most patients (74\%) had poor retrieval, both in patients with frequent seizures (71\%) and low seizure frequency $(68 \%)$. Other investigators had found the same results, that seizure frequency did not influence memory. ${ }^{3,4,15,20}$ As indicated by Dodrill, it may be the total lifetime number of seizures (rather than seizure frequency) which is the crucial variable. ${ }^{15,20}$ The severity of the attack may also be an important factor. However, it must always be borne in mind that seizure frequency or severity may reflect the extent and nature of any underlying brain pathology. ${ }^{15}$

Brain damage already exists in chronic epilepsy, proven by excess of exytotoxins in the epileptic focus 4 and reduction of interictal regional blood flow. ${ }^{21}$ Consequently even in patients with low seizure frequency the destructive process goes on, resulting in brain damage which may influence memory functions.

In this study memory impairment was more frequently found in epilepsy with early age at onset (under 10 years). This conforms with Dikmen et al which also found the same thing. ${ }^{22}$ Meanwhile Loiseau et al discovered more frequent memory impairment in epilepsy with onset during adolescence (10-17 years)., ${ }^{3,15}$

An early age at onset is a recognized deleterious factor. ${ }^{4}$ This fact is not surprising, because childhood is a very important period for learning, a period during which one learns how to learn. Meanwhile epilepsy is a chronic process resulting in reduction of regional bloodflow ${ }^{21}$ and brain damage, especially in the hippocampus. ${ }^{23}$ However, in the studies mentioned earlier although there was a tendency of greater memory impairment in early onset epilepsy, the results were not statistically significant. The suggestion is that many factors are involved in the determination of memory impairment and that this variable are only one of many that are involved. ${ }^{20}$ 
Several anti-epileptic drug can contribute to disorders of memory, including phenobarbital which was used in this study. ${ }^{15,18}$ This study revealed poor retrieval scores in most patients, both in the low dose and the high dose group. Meanwhile Camfield discovered that serum phenobarbital concentration influenced memory, ${ }^{18}$ but other investigators could not prove the relationship. ${ }^{3,24}$

In general, the most dramatic effects of anti-epileptic drugs have been reported in patients on polytherapy or with high levels of medication. ${ }^{15,18}$ This study used subjects receiving therapeutic dose of only one kind of drug, although without serum drug concentration monitoring. And the results showed that drug dose did not influence retrieval scores.

On the effects of phenobarbital on memory there is still controversy, in general penobarbital has worse effects compared to other drugs but the difference may be subtle. ${ }^{3,15,26}$ It was proved that phenobarbital infuenced short term memory, and had no effect on long term memory. The Selective Reminding Test used in this study evaluated retrieval from long term memory, consequently phenobarbital had little effect on the test scores. Finally it has to be borne in mind that interpreting investigations of this kind is difficult, since any negarive drug effects would be expected to be offset by improved seizure control. ${ }^{15,20}$ So it was not unexpected that we found no infuence of drug dose on memory disturbance.

The advantage of using the Selective Reminding Test is that we can analyze the parts of the memory processes impaired. Until recently the parts of memory processes impaired by epilepsy are not well defined. ${ }^{4}$ With this test we can evaluate storage, retention and retrieval in disordered memory. ${ }^{27}$ This information is important to enhance our knowledge in the fields of memory and epilepsy.

In this study both epilepsy groups had the same mean of initial storage, but different storage/ retrieval (S/R) ratio. The $\mathrm{S} / \mathrm{R}$ ratio of most of the $\mathrm{CP}$ group was 0.5 or less, only 3 subjects the ratio was 1 . Further analysis of the CP group showed (Table 6) only one subject (subject no.1) had very poor retrieval (score 15), and the other 2 subjects (no. 6 and 8) had relatively good retrieval (score 5 and 6). Meanwhile in the GTC group more than $50 \%$ subjects the $S / R$ ratio was more than 0.5 .

From these facts we can conclude that initial storage occured earlier in CP epilepsy, and difficulties in recalling items was caused by retrieval disturbance of items in storage. Meanwhile in GTC epilepsy the disturbance is in initial storage, difficulties in recalling items are caused by retrieval impairment and items not yet in storage. Items can enter long term storage when there is attention. ${ }^{28,29}$ Patients who have difficulty maintaining attention will have difficulty in learning. There is some evidence that attentional difficulties can be found in some subgroups of patients with epilepsy and that individuals with generalized seizures are at most risk. ${ }^{15}$ This fact could explain the difference in initial storage in both epilepsy groups.

\section{CONCLUSION}

In this study most cases of epilepsy (75\%) had poor retrieval, and retrieval was not influenced by seizure type, seizure frequency or anti-epileptic drug dose. Although it was statistically not significant, there was a tendency of greater retrieval difficulties in individuals with early age at onset. It was also discovered that in GTC epilepsy there was greater difficulties in intial storage compared to $\mathrm{CP}$ epilepsy.

In conclusion, there is memory disturbance in epileptic patients, but this study could not find the factors that influence it. If considered individually, none of the factors concidered accounted for this impairment. The memory disturbance in epilepsy is probably a multifactorial disability. Besides that epilepsy is an on going process even interictally, resulting in brain damage though the patient appears normal.

Memory disturbance in epileptic patients merits special attention, since it can disturb their lives. To evaluate memory deficit in epilepsy the Selective Reminding Test can be used.Other factors like attention disturbance, concentration and emotion (i.e. depression) in patients with epilepsy need special attention; because they can also influence memory. Further studies are needed with greater sample size and on patients not on medication to exclude drug effects on memory.

\section{REFERENCES}

1.Porter RJ. Classification of epileptic seizures and epileptic syndromes. In: Laidlaw J, Richens A, Chadwick D, eds. A Textbook of Epilepsy. 4th ed. Edinburg: Churchill Livingstone, 1993:1-22.

2. Hauser WA, Annegers JF. Epidemiology of epilepsy. In: Laidlaw J, Richens A, Chad- wick D. A Textbook of Epilepsy. 4th ed. Edinburg: Churchill Livingstone, 1993: 23-45. 
3. Loiseau P, Strube E, Broustet D, Battellochi S, Gomeni C, Morselli PL. Leaming impaiment in epileptic patients. Epilepsia 1983; 24: 183-92.

4. Loiseau P, Strube E, Signoret JL. Memory and epilepsy. In: Trimble MR, Reynolds EH, eds. Epilepsy, Behaviour and Cognitive Function. Stratford-upon-Avon Symposium, November 1987. Chichester: John Wiley and Sons, 1988: 165-73.

5. Bornstein RA, Pakalnis A, Drake ME, Suga LJ. Effects of seizure type and waveform abnormality on memory and attention. Arch Neurol 1988; 45: 884-7.

6. Dodrill CB. Neuropsyhology of epilepsy. In: Filskov SB and Boll TJ, eds. Handbook of Clinical Neuropsychology. New York: John Wiley \& Sons, 1981: 287-319.

7. Loiseau P, Strube E, Signoret JL. Memory and epilepsy. In: Trimble MR, Reynolds EH, eds. Epilepsy, Behaviour and Cognitive Function. Stratford-upon-Avon Symposium, November 1987. Chichester: John Wiley and Sons, 1988: $165-73$.

8. Smith DB, Craft BR, Collins J, et al. Behavioral characteristics of epilepsy patients compared with normal controls. Epilepsia 1986; 27(6): 760-8.

9. Buschke H. Spontaneous remembering after recall failure. Science 1974; 184: 579-81.

10. Yunus MS. Gangguan Memori Pada Penderita Pasca Cedera Kepala; Suatu Evaluasi Dengan Pengingatan Selektif. Tesis.Fakultas Pasca Sarjana Universitas Indonesia, 1987.

11. Dodrill CB. Neuropsyhology of epilepsy. In: Filskov SB and Boll TJ, eds. Handbook of Clinical Neuropsychology. New York: John Wiley \& Sons, 1981: 287-319.

12. Glowinski H. Cognitive deficits in temporal lobe epilepsy. An investigation of memory functioning. J Nerv Ment Dis 1973; 157: 129-37.

13. Mungas D, Ehlers C, Walton N, McCutchen CB. Verbal learning differences in epileptic patients with left and right temporal obe foci. Epilepsia 1985; 26(4): 340-5.

14. Matthews CG, Klove H. Differential psyhological performances in major motor, psy- chomotor and mixed seizure classifications of known and unknown etiology. J Nerv Ment Dis $1973 ; 157: 129-37$.

15. Thompson PJ. Memory function in patients with epilepsy. In: Smith D, Treiman D, Trimble M, eds. Advances in Neurology. Vol 55. New York: Raven Press, 1991: 369-84.
16. Carlson NR. Physiology of Behavior. 4ed ed. Boston: Allyn and Bacon, 1991: 434-510.

17. Trimble MR. The Psychoses of Epilepsy. New York: Raven Press, 1991: 14-23.

18. Camfield CS, Chaplin S, Doyle AB, Shapiro SH, Cummings C, Camfield PR. Side effects of phenobarbital in toddlers: behavioral and cognitive aspects. J Pediatr 1979; 95: 361-5.

19. Meador KJ, Loring DW, Huh K, Gallagher BB, King DW Comparative effects of anti- convulsants. Neurology 1990;40:391-4.

20. Dodrill CB. Neuropsyhology of epilepsy. In: Filskov SB and Boll TJ, eds. Handbook of Clinical Neuropsychology. New York: John Wiley \& Sons, 1981: 287-319.

21. Homan RW, Paulman RG, Devous MD, Walker P, Jennings LW, Bonte FJ. Cognitive function and regional cerebral blood flow in partial seizures. Arch Neurol 1989; 46: $964-$ 70.

22. Dikmen S, Matthews CG, Harley JP. The effect of early versus late onset of major motor epilepsy upon cognitive-intelectual performance. Epilepsia 1975; 16: 73-81.

23. Sass KJ, Spencer DD, Kim JH, Westerveld M, Novelly RA, Lencz $T$. Verbal memory impairment correlates with hippocampal pyramidal cell density. Neurology 1990; 40: 16947.

24. Mac Leod C, Dekaban AS, Hunt E. Memory impairment in epileptic patients: Selective effects of phenobarbital concentration. Science 1978; 202: 1102-4.

25. Matthews CG, Harley JP. Cognitive and motor-sensory performances in toxic and non- toxic epileptic subjects. Neurology $1975 ; 25: 184-8$

26. Meador KJ, Loring DW, Allen ME, et al. Comparative cognitive effects of carbamaze- pine and phenytoin in healthy adults. Neurology $1991 ; 41: 1437-540$.

27. Buschke H, Altman P. Evaluating storage, retention and ritrieval in disordered memory and learning. Neurology 1974; 24 : 1019-25.

28. Lavine RA. Neurophysiology: The Fundamentals. Lexington: The Collamore Press, 1983: 151-5.

29. Russel EW. The pathology and clinical examination of memory. In: Filskov SB, Boll TJ, eds. Handbook of Clinical Neuropsychology. New York: John Wiley and Sons, 1981: 287-319. 